\title{
Improved Sampling Methods for Real-Time Polymerase Chain Reaction Diagnosis of Citrus Canker from Field Samples
}

\author{
Vessela Mavrodieva, Laurene Levy, and Dean W. Gabriel
}

First and second authors: U.S. Department of Agriculture APHIS, PPQ, CPHST-NPGQC, Beltsville, MD 20705; and third author: Plant

Pathology Department, University of Florida, 1453 Fifield Hall, Gainesville 32611.

Current address of V. Mavrodieva: North Carolina State University, Department of Plant Pathology, Raleigh 27695.

Accepted for publication 14 August 2003.

\begin{abstract}
Mavrodieva, V., Levy, L., and Gabriel, D. W. 2004. Improved sampling methods for real-time polymerase chain reaction diagnosis of citrus canker from field samples. Phytopathology 94:61-68.

Citrus bacterial canker disease has been introduced at least three times into Florida in the last 15 years and, despite federal and state quarantine and eradication efforts, continues to spread in Florida. Accurate, fast, and reliable detection of the causal agent is of great importance. However, citrus bacterial canker is caused by at least two groups of phylogenetically distinct Xanthomonas citri strains, and there is host range variation within both groups. We developed a fast, sensitive and reliable real-time

polymerase chain reaction (PCR) assay using a portable, field-hardened RAPID machine and primers designed to detect all canker-causing strains. Single-lesion sampling methods were developed that required minimal handling and allowed complete real-time PCR diagnosis in a total time of $4 \mathrm{~h}$ and with an apparent sensitivity of less than $10 \mathrm{CFU}$ of target cells from diseased lesions. This sensitivity allowed molecular detection for the first time of $X$. citri in a herbarium sample from a 1912 canker outbreak. Sensitivity was improved significantly by the use of $\mathrm{CaCO}_{3}$ and Silwet L-77, and by either minimizing the amount of citrus lesion tissue sampled or by soaking or swiping but not grinding the lesions. Primer design also was of significant importance in both specificity and sensitivity.
\end{abstract}

The increasing presence of Asiatic citrus canker in Florida now threatens various aspects of its $\$ 9$ billion dollar industry. The disease was first identified in the United States in Florida in 1912 and subsequently was eradicated (31). A second outbreak of Asiatic canker occurred in $1986(11,30)$ and was declared eradicated in 1994. In 1995, a third Asiatic citrus canker outbreak was found in urban Miami (12,27). In 1997, a new outbreak of Asiatic citrus canker was found on the west coast of Florida, which possibly was the result of incomplete eradication of the 1986 outbreak (26). Finally, a fifth outbreak, caused by a new strain of citrus canker, termed the "Wellington" strain $\left(\mathrm{A}^{\mathrm{W}}\right)$, was found in Florida in 1999 (32). A joint state and federal effort to eradicate citrus canker, the Florida Citrus Canker Eradication Program (CCEP), is underway, managed by APHIS and the Florida Department of Agriculture and Consumer Services (FDACS). The cost of the CCEP currently exceeds $\$ 200$ million (1). For comprehensive reviews of citrus canker biology, spread, and eradication in Florida, please refer to Schubert et al. (26) and Gottwald et al. (13).

Citrus canker spreads locally and over short distances by winddriven rain and sometimes by high-pressure sprays. Long-distance spread occurs from the movement of infected plant materials or contaminated equipment. Detection of citrus canker bacteria on equipment, on exposed trees, or in preclinical lesions (less than 3 months old) is difficult. Introduction of the citrus leaf miner, Phyllocnistis citrella Stainton, into Florida in 1993 (16) complicates visual canker detection by inspectors because leaf miners cause extensive damage to the foliage. Leaf miners also increase the level of citrus canker inoculum in infected leaves by both wounding leaves and spreading bacterial infection within the

Corresponding author: D. W. Gabriel; E-mail address: gabriel@biotech.ufl.edu

Publication no. P-2003-1024-01R

This article is in the public domain and not copyrightable. It may be freely reprinted with customary crediting of the source. The American Phytopathological Society, 2004. leaf during feeding and formation of extensive galleries within leaves (13).

Despite the best efforts of government and state agencies and the citrus industry, citrus canker still is spreading in Florida, and the infected area under quarantine continues to grow. In 1995, the infected area was $14 \mathrm{mi}^{2}\left(36.3 \mathrm{~km}^{2}\right)$ in a residential area of Miami. In the spring of 2002, the infected area encompassed $657 \mathrm{mi}^{2}$ $\left(1,702 \mathrm{~km}^{2}\right)$ and over 2.1 million infected commercial, residential, or exposed residential trees have been removed. A diagnosis of citrus canker results in the destruction of infected trees and also all "exposed" trees-those within a radius of $1,900 \mathrm{ft}(589 \mathrm{~m})$ of any infected tree (an area of $\approx 0.4 \mathrm{mi}^{2}$ or $1 \mathrm{~km}^{2}$ ). In addition to the removal of infected and exposed trees, successful control and eradication requires reliable and fast on-site diagnosis of the disease both within the quarantine zones and at ports of entry to prevent new introductions.

Any strain capable of causing cankers (hyperplastic symptoms) on any citrus host is subject to quarantine and eradication; therefore, accurate detection and diagnosis of any and all cankercausing strains, including new ones, regardless of origin or host range, is of extreme importance for successful control and eradication of the disease. Currently, citrus canker is detected visually by identification of disease symptoms on infected trees. Suspect positive samples are sent to diagnostic labs, where the lesions are examined and bacterial cultures are taken. These cultures then are used for reinoculation on citrus and for enzyme-linked immunosorbent assay (ELISA) and polymerase chain reaction (PCR) testing. The need for rapid methods of canker detection to complement and confirm visual detection is obvious. Laboratory tests to confirm visually suspected canker infections are complicated by phylogenetic variation among canker-causing xanthomonads.

Throughout this article, we use Xanthomonas citri to refer to any xanthomonad capable of causing hyperplastic cankers on citrus, and nomenclature for its pathovars as proposed by Brunings and Gabriel (2). Citrus canker disease is caused by two phylogenetically distinct, clonal groups of Xanthomonas strains, one 
originating from Asia (X. citri pv. citri groups) and the other from South America (X. citri pv. aurantifolii groups); each group has subgroups that differ significantly in host range and, therefore, also are true pathogenic variants $(2,8,9)$. By far the most predominant and widespread subgroup or pathovar is the Asiatic or $X$. citri pv. citri A strains, with a host range that includes all citrus cultivars. Much less widespread are the $X$. citri pv. citri A* strains from southwest Asia (40). Most recently, a third pathogenic variant strain, apparently of Asiatic origin, designated $\mathrm{A}^{\mathrm{w}}$, was found in one location in Florida (32). The South American citrus canker strains also comprise at least two subgroups or pathovars. Symptoms on susceptible hosts caused by the South American strains are identical to those caused by Asiatic strains, but all South American strains are limited in host range: $X$. citri pv. aurantifolii B strains are found primarily on lemon and lime, and $X$. citri pv. aurantifolii $\mathrm{C}$ strains are limited to Mexican lime.

Identical symptoms induced by phylogenetically distinct groups of strains is indicative of a common pathogenicity factor. Gene pthA is essential for $X$. citri pv. citri A to elicit cankers on citrus, and pthA confers this ability to various $X$. campestris strains (for example, $X$. campestris pvs. alfalfae and citrumelo) $(33,34)$. Functionally homologous genes ( $p t h B$ and $p t h C)$ also have been identified and cloned from $X$. citri pv. aurantifolii B and $\mathrm{C}$, respectively (7). Both $p t h B$ and $p t h C$ are essential for $X$. citri pv. aurantifolii $\mathrm{B}$ and $\mathrm{C}$ strains, respectively, to cause cankers on citrus, and both $p t h B$ and $p t h C$ confer this ability to various $X$. campestris strains (7). All three genes, therefore, are functionally interchangeable, and these genes may have been transferred horizontally on plasmids between $X$. citri and $X$. citri pv. aurantifolii strains (2). These genes belong to a large family of avirulence or pathogenicity genes found only in the genus Xanthomonas (the avrBs3/pthA gene family); all members of the pthA gene family are long $(>3.8 \mathrm{~kb})$ and all have a remarkably high level of DNA sequence identity $(>90 \%)$ over their entire lengths $(6,18)$. Based on DNA hybridizations, apparently homologous genes are found in all canker-causing strains, and have not been found in noncanker-inducing strains isolated from citrus, such as $X$. campestris pv. citrumelo $(3,7)$. Therefore, a single common gene appears to be diagnostic (and necessary) for a Xanthomonas strain's ability to induce cankers on citrus (2).

All existing conventional PCR methods for canker detection require gel visualization or utilize primers that do not detect all strains $(4,14,15)$. For example, PCR primers designed by Hartung et al. $(14,15)$ and by Kingsley et al. (17) work very well for detection of $X$. citri pv. citri A, but neither are consistent for detection of $X$. citri pv. aurantifolii B or C strains. Recently, Cubero and Graham (3) described new PCR primers based on the pthA gene sequence that failed to detect only one canker strain tested. There is an urgent need for a rapid assay with universal and highly specific primers able to detect all canker-causing strains. To increase the speed of diagnosis, the assay also needs to (i) be portable, (ii) require minimal sample handling, and (iii) work with suboptimal (old, partially degraded, or stored) field samples.

Real-time PCR technology offers sensitive, reliable, and fast detection and identification of plant pathogens. Compared with conventional PCR, real-time PCR is simpler to perform, less labor-intensive (no agarose gels required), and much faster. Accurate results can be observed in less than $1 \mathrm{~h}$ if the sampling method is reliable. Real-time PCR is becoming increasingly useful for the detection of all plant pathogens: fungi $(22,38,39)$, bacteria $(20,24$, 25,37 ), and viruses $(21,23,28)$. For a comprehensive review of real-time PCR principles and amplicon detection methods, refer to Mackay et al. (19). We report here a sensitive and reliable SYBR Green real-time PCR assay based on sampling methods performed on field samples using primers designed to amplify conserved regions of a required pathogenicity gene and, therefore, capable of detecting all known strains of citrus canker.

\section{MATERIALS AND METHODS}

Citrus canker strains. Citrus canker strains used for developing the assay are listed in Table 1.

Diseased citrus samples. Field samples of citrus leaves and fruit infected with canker in Florida were provided by the FDACS, Division of Plant Industry (DPI) at their Quarantine Greenhouse in Gainesville, FL or were taken directly in the field in Florida by United States Department of Agriculture APHIS personnel. For test development, grapefruit leaves were artificially infected with canker by dipping citrus leaves in X. citri pv. citri A $3213^{\mathrm{T}}$ at $\approx 5,000 \mathrm{CFU} / \mathrm{ml}$ in $\mathrm{CaCO}_{3}$-saturated sterile tap water containing Silwet L-77 (OSI Specialties, Inc., Friendly, WV) at 200 ppm. This resulted in highly uniform inoculations of well-dispersed citrus canker lesions. All such inoculations were performed in the FDACS/DPI quarantine greenhouse. Healthy, uninfected samples were taken from a different (canker-free) greenhouse.

PCR primers. Primers were designed using Primer Express software (version 2.0; Applied Biosystems, Foster City, CA). They were designed specifically for real-time PCR and selected to amplify relatively short fragments from highly conserved regions found in all members in the pthA gene family, including: pthA (GenBank accession U28802), pthB (Gabriel lab, unpublished sequence), pthC (Gabriel lab, unpublished sequence), apll (AB021363), apl2 (AB021364), apl3 (AB021365), pthA1, pthA2, pthA3, and pthA4 (the latter four all in GenBank Accession No. AE008925). Three pairs of primers were evaluated and their annealing positions on pthA (U28802) are as follows (odd number for forward primers, even for reverse): VM1 (5'-GATCAAAAGAACCAATCGCCGTAT; 3,388 to 3,411), VM2 (5'-GGGAGTGGCACTGGAAAAAACC; 3,467 to 3,488), VM3 (5'-GCATTTGATGACGCCATGAC; 3,500 to 3,519 ), VM4 (5'-TCCCTGATGCCTGGAGGATA; 3,631 to 3,650), VM5 (5'-AACAGGAGAAGATCAAACCGAAGGTT; 1,086 to 1,111$)$, and VM6 (5'GTTTGCGCACGCCAACGAT; 1,268 to 1,286 ). Another pair of real-time PCR primers designed by Kingsley et al. (17) also were evaluated and are referred to as Kingsley's primers in the remainder of the article (Kingsley forward, 5'-TCCACTGCATCCCACATCTG; Kinsgley reverse, 5'-CAGGTGTACTGCGCTCTTCTTG; GenBank Accession No. AF312370). These primers appear to anneal to the $X$. citri pv. citri A chromosome (GenBank Accession No. NC_003919) from positions 1,217,824 to $1,217,949$, and amplify an apparently noncoding intergeneric region between genes XAC1061 and XAC1062.

TABLE 1. Citrus canker strains used

\begin{tabular}{|c|c|c|c|}
\hline Strains & Strain description & Host range & Source or reference \\
\hline Xanthomonas citri pv. citri $3213^{\mathrm{T}}$ & Species type strain, A strain from Florida & All citrus species & Gabriel et al. 1989 (9) \\
\hline $3213 \mathrm{Sp}^{\mathrm{R}} \mathrm{Rif}^{\mathrm{R}}$ & Spontaneous $\mathrm{Sp}^{\mathrm{R}}$, Rif $^{\mathrm{R}}$ derivative of $\mathrm{Xc} 3213^{\mathrm{T}}$ & All citrus species & Gabriel lab strain \\
\hline 205 & $\mathrm{~A}^{*}$ strain from Oman & Lime & Verniere et al. 1998 (40) \\
\hline 0053 & $\mathrm{~A}^{\mathrm{W}}$ strain from Florida & Lime & Sun et al. $2000(32)$ \\
\hline \multicolumn{4}{|l|}{$X$. citri pv. aurantifolii } \\
\hline B69 & B strain from South America & Lemon, lime & Gabriel et al. 1988 (9) \\
\hline C340 & C strain from South America & Lime & Gabriel et al. 1988 (9) \\
\hline X. campestris pv. citrumelo 3048 & Bacterial spot strain from Florida & Nursery citrus of many cultivars & Gabriel et al. 1989 (10) \\
\hline
\end{tabular}


Real-time PCR conditions. Real-time PCR detection of citrus canker was performed on a mobile RAPID 7200 system (Idaho Technology, Salt Lake City, UT) using SYBR Green I (Molecular Probes, Eugene, OR) fluorescent dye detection. Each sample was run in duplicate in glass capillaries tubes (Roche Diagnostics, Indianapolis, IN). Every run included negative (no target DNA) and positive (target DNA) controls. The PCR reactions contained $2 \mu \mathrm{l}$ of sample supernatant or purified DNA extracted from culture-grown cells added to $18 \mu \mathrm{l}$ of reaction mix. Reaction mix consisted of $1 \times$ PCR buffer with bovine serum albumin (Idaho Technology), $2 \mathrm{mM} \mathrm{MgCl}_{2}, 0.5 \mu \mathrm{M}$ each primer, $0.2 \mathrm{mM}$ dNTPs, $2 \mu \mathrm{l}$ of 1:3,000 SYBR Green I, and 0.8 units of Taq Polymerase (Roche Diagnostics). For hot-start PCR, Taq Polymerase was incubated with TaqStart Antibody (Clontech, Palo Alto, CA) 1:28 ( $\mathrm{vol} / \mathrm{vol}$ ) for $10 \mathrm{~min}$ at room temperature before adding to the reaction mix. The PCR program conditions for the VM3 and 4 primer pair are given as "Program 1"; PCR program conditions using Kingsley's primers were performed according to Kingsley et al. (17) and are given as "Program 2" in Table 2.

PCR assay optimization, crossing point definition, and melting curve analysis. In real-time PCR, the total SYBR Green fluorescence detected after each amplification cycle provides a measure of PCR product formation. The process is monitored in real time and graphically displayed as a semilog curve of the accumulating SYBR Green fluorescence over the number of cycles (Fig. 1A). The crossing point $(\mathrm{Cp})$ of each graphical curve is defined as the cycle in which the level of fluorescence of the particular sample increases above the background. The $\mathrm{Cp}$ is used as one criterion to determine target presence or absence and also indicates the concentration of the target. Higher target concentrations will result in lower $\mathrm{Cp}$ values, thus allowing reliable quantification of purified DNA (Fig. 1B).

A melting curve analysis was used as a second criterion to determine target presence or absence, because it assists in detecting false-positive PCR product formation. Each PCR product exhibits a characteristic peak at its melting temperature (Tm) maximum. The melting curve analysis was used to identify nontarget PCR product and primer-dimer formation. All results reported are based on both the $\mathrm{Cp}$ values and melting curve analyses.

PCR assay optimization was performed using $10 \mathrm{ng}$ of purified DNA from all 5 citrus canker inducing strains and from $X$. campestris pv. citrumelo. A water control also was included. All three primer pairs were evaluated at 2, 3, 4, and $5 \mathrm{mM}$ concentrations of $\mathrm{Mg}$ and annealing temperatures of 55 and $57^{\circ} \mathrm{C}$. Kingsley's primers were run at the recommended conditions (Table 2, program 2). Each sample $(10 \mu \mathrm{l})$ was loaded on $2 \%$ agarose gels and stained with ethidium bromide to make sure that the $\mathrm{Cp}$ and melting peak observed for each sample in real-time PCR corresponded to a band of expected size on the gel.

Real-time PCR sensitivity and reproducibility. Ten-fold serial dilutions of purified $X$. citri pv. aurantifolii B DNA were run six times and the $\mathrm{CV}$ (mean coefficient of variation) of the $\mathrm{Cp}$ values estimated. DNA (10 to $15 \mu \mathrm{g}$ ) was used as a positive control in every test run, and these controls always gave $\mathrm{Cp}$ values between 17 and 20. Additionally, X. citri pv. citri A 3213 and X. citri pv. aurantifolii B69 cells were cultured in peptone, yeast
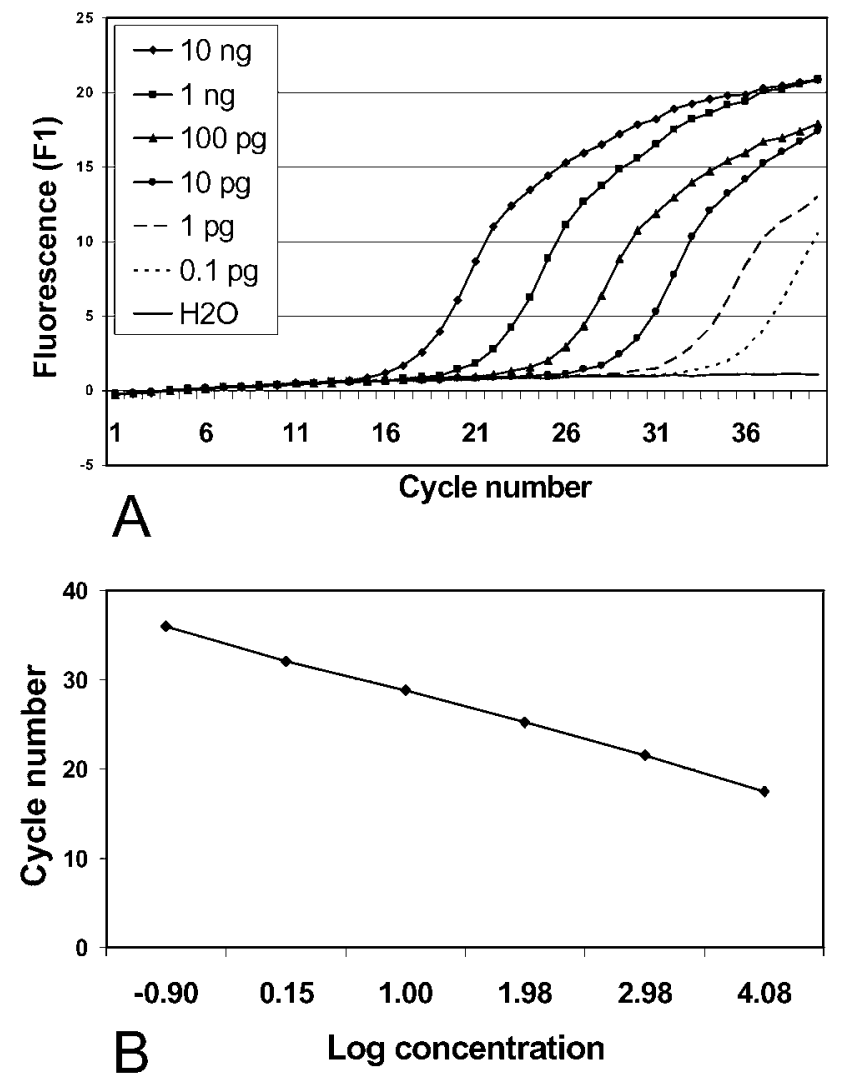

Fig. 1. Real-time polymerase chain reaction assay optimization with the VM3 and 4 primer pair illustrating sensitivity and linearity. A, Amplification plot of 10-fold serial dilutions of Xanthomonas citri pv. aurantifolii B DNA control in a single experiment. B, Standard curve for the same experiment, based on the calculated serial dilution points and corresponding crossing point $(\mathrm{Cp})$ values. Standard curve parameters: Slope, -3.739 ; intercept, 32.65 ; error, 0.168 ; and $r,-1.00$.

TABLE 2. Real-time polymerase chain reaction program parameters set up ${ }^{\mathrm{a}}$

\begin{tabular}{|c|c|c|c|c|c|c|}
\hline Program & $\begin{array}{l}\text { Number of } \\
\text { cycles }\end{array}$ & Steps & Temperature $\left({ }^{\circ} \mathrm{C}\right)$ & Hold time (s) & $\begin{array}{c}\text { Temperature transition } \\
\text { rate }\left({ }^{\circ} \mathrm{C} / \mathrm{s}\right)\end{array}$ & Fluorescence \\
\hline \multicolumn{7}{|l|}{ Program 1} \\
\hline Denaturation & 1 & 1 & 95 & 120 & 20 & None \\
\hline & $\ldots$ & 2 (anneal) & 57 & 0 & 20 & None \\
\hline & $\ldots$ & 3 (extension) & 72 & 12 & 2 & Single \\
\hline Melting curve analysis & 1 & 1 (denature) & 95 & 5 & 20 & None \\
\hline Denaturation & 1 & 1 & 95 & 120 & 20 & None \\
\hline \multirow[t]{3}{*}{ Amplification } & 40 & 1 & 95 & 5 & 20 & None \\
\hline & $\ldots$ & 2 & 54 & 0 & 20 & None \\
\hline & $\ldots$ & 3 & 72 & 15 & 2 & Single \\
\hline \multirow{2}{*}{ Melting curve analysis } & 1 & 1 & 95 & 5 & 20 & None \\
\hline & $\ldots$ & 2 & 40 & 90 & 20 & None \\
\hline
\end{tabular}

${ }^{a}$ Each program follows the indicated processes of denaturation, amplification, and melting curve analysis; the steps within each process are repeated in the indicated number of cycles. Fluorescence was acquired in channel F1 and the gain setting was 8. 
extract, glucose, and MOPS (PYGM) (10) liquid medium to an optical density of 0.5 at $600 \mathrm{~nm}$. Ten-fold serial dilutions of these cultures were made and used for real-time PCR with VM3 and 4 primers. The same dilutions were used for cell count $-5 \mu \mathrm{l}$ of each dilution was plated on PYGM agar, plates were incubated for 18 to $24 \mathrm{~h}$ at $30^{\circ} \mathrm{C}$, and $\mathrm{CFU}$ were counted.

Citrus canker detection in greenhouse and field samplessample preparation. Single lesions of similar size and condition were cut out of infected citrus leaves using a no. 1 (smallest standard, $\approx 4 \mathrm{~mm}$ in diameter) or no. 3 ( $\approx 6 \mathrm{~mm}$ in diameter) cork borer. For experiments designed to optimize extraction buffers and protocols, nearly identical, young, single lesions of similar age were placed in Eppendorf tubes containing $100 \mu \mathrm{l}$ of one of the following solutions: (i) sterile tap water; (ii) phosphate-buffered saline $(0.7 \%)$ in sterile tap water, $\mathrm{pH} 7.0$ (PBS); (iii) saturated $\mathrm{CaCO}_{3}$ in sterile tap water; (iv) Silwet L-77 in sterile tap water 1:5,000 (vol/vol); (v) Silwet L-77 in saturated $\mathrm{CaCO}_{3}$ in sterile tap water 1:5,000 (vol/vol); or (vi) 5\% Chelex 100 (Sigma Chemical, St. Louis) in Silwet L-77 in saturated $\mathrm{CaCO}_{3}$ in sterile tap water $1: 5,000$ ( $\mathrm{vol} / \mathrm{vol})$. Some of the samples were crushed with plastic disposable pestles (Kontes Scientific, Vineland, NJ) directly in 1.5-ml Eppendorf tubes after combining with extraction solution.

All samples, whether crushed or not, were shaken vigorously on a reciprocal shaker (250 cycles/min) for $1 \mathrm{~h}$ at room temperature and plant debris were pelleted by centrifugation for $5 \mathrm{~min}$ at $5,000 \mathrm{rpm}$. The resulting supernatants were transferred to new tubes and $2 \mu \mathrm{l}$ of each was used directly for real-time PCR assays. To evaluate assay sensitivity with leaf samples, 10-fold serial dilutions of the supernatants were made and tested by real-time PCR. For viable cell counts, $2-\mu$ droplets of the same dilutions were plated in duplicates on PYGM agar, the plates were incubated at $30^{\circ} \mathrm{C}$, and $\mathrm{CFU}$ were counted. When artificial inoculations of $3213 \mathrm{SpR}$ were used, rifampicin $(75 \mu \mathrm{g} / \mathrm{ml})$ and spectinomycin $(35 \mu \mathrm{g} / \mathrm{ml})$ were added to the agar medium.

In order to compare effectiveness of the different sample preparations from multiple experiments using canker lesions of different age and quality, a scoring scale of 0 to 4 was used to semiquantify target concentrations in terms of $\mathrm{Cp}$ values. A score of 0 indicated no detectable target (no $\mathrm{Cp}$ and Tm peak); a score of 4 indicated the highest level of target concentration. A score of 4 was assigned when the $\mathrm{Cp}$ occurred before the twentieth PCR cycle (Cp value of $<20$ ); scores of 3,2 , and 1 indicated $\mathrm{Cp}$ values of 20 to 30,30 to 35 , and 35 to 40, respectively. In all cases except 0 , a specific Tm peak was confirmed to be present.

Field sample detection using the IT 1-2-3 RAPID DNA purification kit. The IT 1-2-3 RAPID DNA Purification Kit (the IT kit; Idaho Technology) was used in two double-blind tests. Field samples from freshly discovered canker-infected lesions and also from healthy leaves and fruit were collected from cankerinfested zones in Florida. These samples were taken from lesions that were identified unambiguously in the field as canker infected. Leaves and fruit were simply swiped with moistened swabs provided with the kit. The swabs then were placed inside tubes containing ceramic beads suspended in water provided with the kit, and the samples were encoded and mailed under quarantine permit for lab processing. Samples collected in this manner were stored for up to 1 week at $4{ }^{\circ} \mathrm{C}$ prior to processing. Samples were processed according to the manufacturer's instructions. Basically, samples were vortexed for $5 \mathrm{~min}$ and DNA extraction buffer provided in the kit (guanidine HCL, isopropanol, and sodium acetate) was added. The solution was centrifuged and the supernatant run over a filtration spin column provided. The column was washed once and the DNA was eluted in $100 \mu$ l of elution buffer, and used directly for real-time PCR analysis. After performing the PCR tests, results were recorded and sample numbers were decoded.

Herbarium samples. Dry, nonviable herbarium samples collected during the 1912 Florida canker outbreak were received from the FDACS (Gainesville) collection and processed in APHIS labs in Beltsville. Extreme care was exercised to open and process the herbarium samples in lab areas not exposed to canker. Single lesions were cut out of dried citrus leaves with individual razor blades, placed in Eppendorf tubes, and crushed in $\mathrm{CaCO}_{3}-\mathrm{Silwet}$ L-77-Chelex solution. The above-described extraction and realtime PCR protocols were applied using the VM3 and 4 pair and with Kingsley's primers. In addition, $20 \mu \mathrm{l}$ of the crude sample extract supernatant was used for DNA extraction using the IT kit according to the manufacturer's instructions. Precautions were taken to avoid carryover or cross contamination. The expected PCR products were confirmed by DNA sequencing.

\section{RESULTS}

Primer specificity. Using extracted total DNA and culturegrown cells, the VM3 and 4 pair of primers was found to work best at $57^{\circ} \mathrm{C}$ annealing temperature and $2 \mathrm{mM} \mathrm{Mg}^{2+}$, consistently and reliably giving the expected 150 -bp product for representative strains from all five known citrus canker groups or pathovars from Asia or South America: X. citri pv. citri A, X. citri pv. aurantifolii $\mathrm{B}$ and $\mathrm{C}$, and $X$. citri $\mathrm{pv}$. citri $\mathrm{A}^{*}$ and $\mathrm{A}^{\mathrm{W}}$. Under these conditions, all samples had the lowest $\mathrm{Cp}$ and highest fluorescence. Melting curve analyses revealed a Tm peak of $90^{\circ} \mathrm{C}\left( \pm 1^{\circ} \mathrm{C}\right)$ for the 150 -bp products from all representative strains. No fragments were pro-

TABLE 4. Combined real-time polymerase chain reaction scores using different sample preparation methods for both field and greenhouse samples ${ }^{\mathrm{a}}$

\begin{tabular}{lccc}
\hline Sample preparation & $\begin{array}{c}\text { No. 3 } \\
\text { cork borer }\end{array}$ & $\begin{array}{c}\text { No. 1 } \\
\text { cork borer }\end{array}$ & $\begin{array}{c}\text { Total } \\
\text { score }\end{array}$ \\
\hline Phosphate-buffered saline & 1.2 & 2.6 & 1.8 \\
$\mathrm{CaCO}_{3}-\mathrm{H}_{2} \mathrm{O}$ & 1.9 & 2.7 & 2.0 \\
${\text { Silwet L-77- } \mathrm{H}_{2} \mathrm{O}}_{\mathrm{CaCO}_{3}-\text { Silwet L-77 }}^{0.9}$ & 2.5 & 1.4 \\
$\mathrm{CaCO}_{3}-$ Silwet L-77, crushed & 2.3 & 2.9 & 2.3 \\
$\mathrm{CaCO}_{3}-$ Silwet L-77-Chelex, crushed & 1.5 & 2.3 & 1.6 \\
\hline
\end{tabular}

a The total score for each preparation represents the average of at least 10 independent experiments using old, dry field samples, relatively fresh field samples, and fresh greenhouse-inoculated samples. Mean score was based on crossing point $(\mathrm{Cp})$ values: $4, \mathrm{Cp}<20$ cycles; $3, \mathrm{Cp}=20$ to $30 ; 2, \mathrm{Cp}=$ 30 to $35 ; 1, \mathrm{Cp}=35$ to 40 , and 0 , no detected $\mathrm{Cp}$ or $\mathrm{Cp}>40$.

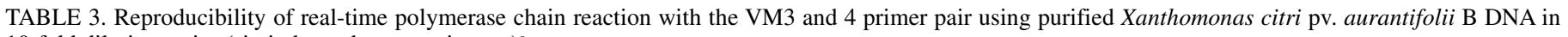
10 -fold dilution series (six independent experiments) ${ }^{\mathrm{a}}$

\begin{tabular}{|c|c|c|c|c|c|c|c|c|c|}
\hline \multirow[b]{2}{*}{$X$. citri DNA } & \multicolumn{9}{|c|}{$\mathrm{Cp}$} \\
\hline & Exp. 1 & Exp. 2 & Exp. 3 & Exp. 4 & Exp. 5 & Exp. 6 & Mean & $\mathrm{SD}$ & $\mathrm{CV}$ \\
\hline $10 \mathrm{ng}$ & 18.8 & 19.3 & 17.3 & 18.7 & 16.9 & 17.5 & 18.08 & 0.97 & 5.37 \\
\hline $1 \mathrm{ng}$ & 21.7 & 23.7 & 21.5 & 23.4 & 21.8 & 21.5 & 22.27 & 1.01 & 4.49 \\
\hline $100 \mathrm{pg}$ & 24.6 & 27.5 & 25.3 & 27.6 & 25.1 & 25.2 & 25.88 & 1.31 & 5.06 \\
\hline $10 \mathrm{pg}$ & 28.1 & 31.1 & 29.1 & 31.2 & 29.7 & 29.1 & 29.72 & 1.22 & 4.10 \\
\hline $1 \mathrm{pg}$ & 32.2 & 37.0 & 32.1 & 36.0 & 32.8 & 33.7 & 33.97 & 2.07 & 6.09 \\
\hline $0.1 \mathrm{pg}$ & 36.8 & 39.0 & 36.2 & ND & ND & ND & ND & ND & ND \\
\hline $\mathrm{H}_{2} \mathrm{O}$ & 0.0 & 0.0 & 0.0 & 0.0 & 0.0 & 0.0 & 0.0 & 0.00 & 0.00 \\
\hline
\end{tabular}

${ }^{\text {a }} \mathrm{Cp}$, crossing point; $\mathrm{SD}$, standard deviation; $\mathrm{CV}$, coefficient of variation; ND, not determined. 
duced using extracts of healthy citrus leaves. No fragments of expected size were amplified with DNA of X. campestris pv. citrumelo, or from extracts of $X$. campestris pv. citrumelo-infected citrus. The VM1-2 amplified $X$. citri pv. aurantifolii C less efficiently and VM5-6 primer pairs failed to react with $X$. citri pv. aurantifolii B and C. Nontemplate controls (water controls) in some runs showed $\mathrm{Cp}$ of 36 and higher. Melting curve analysis for those samples revealed a peak of $\approx 74^{\circ} \mathrm{C}$, characteristic for primerdimer formations. Kingsley's primers gave a prominent band with 3213 (X. citri pv. citri A) and 205 (X. citri pv. citri A*) but the reactions with $\mathrm{B} 69$ (X. citri pv. aurantifolii B), C340 (X. citri pv. aurantifolii $\mathrm{C}$ ), and 0053 (X. citri pv. citri $\mathrm{A}^{\mathrm{W}}$ ) were inconsistent and also gave rise to more primer-dimer products compared with VM3 and 4. The VM3 and 4 primers were selected for further experimentation.

Assay sensitivity and reproducibility. As low as $1 \mathrm{pg}$ of purified total $X$. citri total DNA was reliably detected using the VM3 and 4 primer pair in real-time PCR in repeated experiments; as low as $0.1 \mathrm{pg}$ of purified total $X$. citri DNA was detected in most experiments (Fig. 1A; Table 3). The assay showed quantitative reproducibility over five orders of magnitude of dilutions (Fig. 1B; Table 3). Using X. citri pv. citri A 3213 or X. citri pv. aurantifolii B B69 cultured cells, as few as 10 CFU were detected reliably when added directly to the PCR mix as determined by cell count (data not shown).

Citrus canker detection using greenhouse and field samples. After optimizing the PCR assay with DNA and cultured cells, sampling and extraction procedures were optimized. To provide uniformity, single fresh lesions of the same size and age and, preferably, from the same infected leaf were chosen in the greenhouse to evaluate the different sample preparations. Generally, 2- to 3-month-old lesions from greenhouse-infected grapefruit seedlings were used. In addition, actual field samples received by FDACS from recent outbreaks in Florida were tested. The ages of these samples varied and was difficult to estimate, because field samples often were from old infections when they were first recovered.

Real-time PCR samples of lesions cut out with a no. 1 cork borer ( $4 \mathrm{~mm}$ in diameter) had much lower $\mathrm{Cp}$ (higher score) and much higher values of total fluorescence compared with those cut out with a no. 3 cork borer (6 $\mathrm{mm}$ in diameter), regardless of sample preparation buffer (Table 4). All of the sample preparation buffers performed adequately when using fresh, young, large canker lesions. Samples of crushed lesions had relatively higher $\mathrm{Cp}$ values (lower score) and lower total fluorescence than those which had been shaken only (Table 4; data not shown). Adding Chelex to crushed samples resulted in lower $\mathrm{Cp}$ values and higher total fluorescence (i.e., improved sensitivity; Table 4). Crushing samples and using the $\mathrm{CaCO}_{3}$-Silwet-Chelex mixture seemed especially useful for old, small, and dry field lesions (Table 4; data not shown). Detection of citrus canker from field samples usually resulted in $\mathrm{Cp}$ values that were higher by at least two cycles com- pared with the greenhouse samples for the same buffer or extraction procedure. The sensitivity of detection was likely lower due to the age or conditions of the leaves and lesions, and possibly due to the presence of $\mathrm{Cu}^{2+}$-containing pesticide spray residues on such leaves.

Ten-fold dilutions of the greenhouse canker-inoculated citrus samples were made in order to determine (i) which sample preparation method or methods resulted in the greatest bacterial cell release, (ii) which preparation methods or methods resulted in the greatest detection sensitivity (lowest $\mathrm{Cp}$ value, highest score), and (iii) if there was a correlation between bacterial cell release and detection sensitivity. It is clear (Table 5) that addition of Silwet with $\mathrm{CaCO}_{3}$ resulted in an $\approx 10 \times$ greater increase in $\mathrm{CFU}$ count. Adding $\mathrm{CaCO}_{3}$ to dilute aqueous solutions of Xanthomonas cells can prolong survival (data not shown). Importantly, crushing of the samples did not significantly enhance cell release (CFU count) and actually reduced PCR detection sensitivity, unless Chelex was added to the extraction buffer (Table 5). Evidently, crushing of the sample released a component from citrus that was inhibitory to PCR, even at high dilution levels (Table 5). Cell counts of the dilution series revealed that apparently $<10 \mathrm{CFU}$ was detected reliably with good reproducibility (Table 5). Overall, the simplest and most effective method involved using the smallest practical citrus leaf lesion sample, using Silwet with $\mathrm{CaCO}_{3}$ and shaking or soaking to release bacterial cells while minimizing cell damage.

The IT kit also showed excellent accuracy, sensitivity, and reproducibility in two double-blind tests of clearly infected canker field lesion samples (Table 6). Very low PCR scores were obtained with some of the exposed fruit (healthy fruit surrounded by canker-infected leaves). Similar results were obtained in additional greenhouse tests, indicating the potential sensitivity of this method.

Herbarium sample results. Dry, nonviable herbarium samples collected in Florida during the 1912 outbreak were subjected to the described protocols. Citrus canker DNA was detected in some samples using the VM3 and 4 and Kingsley's primers with relatively high Cp (29 and higher) values. $X$. citri DNA was used as positive control. No $\mathrm{Cp}$ values were detected for water controls (negative PCR control). Bands of expected size were observed when the real-time PCR products were loaded on agarose gels (Fig. 2). The PCR products were cloned and sequenced, revealing the expected amplification product sequences.

\section{DISCUSSION}

Effective control and eradication of citrus canker requires reliable assay specificity. Over a decade ago, pthA was identified as essential for $X$. citri to elicit cankers on citrus (33). This gene or its homologues are found in every $X$. citri strain examined $(3,7)$. When expressed in citrus cells (in the absence of any bacterium), pthA alone causes the hyperplastic cankers and epidermal cell death that are diagnostic of citrus canker disease (5). Because

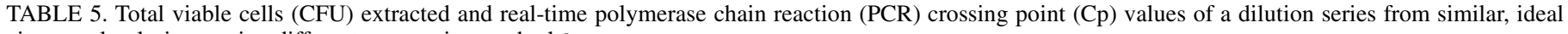
citrus canker lesions, using different preparation methods ${ }^{\mathrm{a}}$

\begin{tabular}{|c|c|c|c|c|c|c|c|}
\hline \multirow[b]{2}{*}{ Extraction method } & \multicolumn{6}{|c|}{$\mathrm{Cp}$ in dilution series } & \multirow[b]{2}{*}{ CFU/lesion $(\mathrm{SD})^{\mathrm{b}}$} \\
\hline & Undiluted & $1 \times 10^{4}$ & $1 \times 10^{5}$ & $1 \times 10^{6}$ & $1 \times 10^{7}$ & $1 \times 10^{8}$ & \\
\hline Phosphate-buffered saline & 15.4 & 25.5 & 30.9 & 35.5 & 38.0 & 0.0 & $6 \times 10^{6}(1.5)$ \\
\hline $\mathrm{CaCO}_{3}$ & 17.8 & ND & ND & ND & ND & ND & $8 \times 10^{6}(3.0)$ \\
\hline Silwet & 18.7 & ND & ND & ND & ND & ND & $5 \times 10^{6}(3.6)$ \\
\hline $\mathrm{CaCO}_{3}-$ Silwet & 16.4 & 26.3 & 30.6 & 34.6 & 38.0 & 0.0 & $4 \times 10^{7}(2.4)$ \\
\hline $\mathrm{CaCO}_{3}-$ Silwet crushed & 20.8 & 27.1 & 32.0 & 35.5 & 0.0 & 0.0 & $9 \times 10^{7}(15.4)$ \\
\hline $\mathrm{CaCO}_{3}-$ Silwet-Chelex crushed & 16.4 & 23.4 & 26.9 & 30.3 & 36.5 & 39.0 & $2 \times 10^{7}(2.8)$ \\
\hline
\end{tabular}

${ }^{a}$ Each value represents the average of three independent experiments of greenhouse-inoculated samples. ND, not determined.

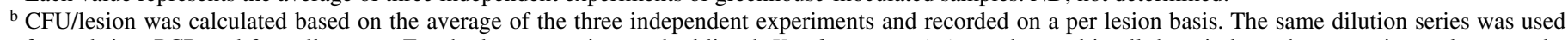
for real-time PCR and for cell counts. For the last extraction method listed, Xanthomonas citri was detected in all three independent experimental runs at the $1 \times 10^{7}$ dilution of $2 \times 10^{7}$ bacteria, allowing a detection sensitivity of an average of $<10$ CFU in these experiments. SD, standard deviation. 
pthA is found in every $X$. citri strain examined and because pthA alone causes canker symptoms, there is no reason to suspect that a xanthomonad could cause citrus canker disease without pthA. Thus, pthA represents an important diagnostic indicator for citrus canker-causing xanthomonads, regardless of their taxonomic

TABLE 6. Double-blind testing of field samples taken in the current Florida citrus canker outbreak, using the IT 1-2-3 RAPID DNA purification kit and real-time polymerase chain reaction $(\mathrm{PCR})^{\mathrm{a}}$

\begin{tabular}{|c|c|c|}
\hline Experiment, vial no.. & Description & $\begin{array}{l}\text { PCR } \\
\text { score }\end{array}$ \\
\hline \multicolumn{3}{|l|}{ Experiment 1} \\
\hline 1 & 6- to 9-month-old lesion & 2 \\
\hline 2 & Healthy & 0 \\
\hline 3 & Healthy & 0 \\
\hline 4 & 6- to 9-month-old lesion & 3 \\
\hline 5 & 3- to 6-month-old lesion & 2 \\
\hline 6 & 6- to 9-month-old lesion & 2 \\
\hline 7 & 3- to 6-month-old lesion & 3 \\
\hline 8 & Healthy & 0 \\
\hline 9 & 3- to 6-month-old lesion & 3 \\
\hline 10 & Healthy & 0 \\
\hline 11 & 3- to 6-month-old lesion & 3 \\
\hline 12 & 6- to 9-month-old lesion & 3 \\
\hline 13 & 3- to 6-month-old lesion & 3 \\
\hline 14 & 6- to 9-month-old lesion & 3 \\
\hline 15 & Healthy & 0 \\
\hline \multicolumn{3}{|l|}{ Experiment 2} \\
\hline 1 & Exposed fruit (2 to 3 months) & 1 \\
\hline 2 & 3-month-old leaf lesion & 2 \\
\hline 3 & 6-month-old fruit lesion & 2 \\
\hline 4 & Exposed fruit (2 to 3 months) & 0 \\
\hline 5 & 6-month-old fruit lesion & 1 \\
\hline 6 & Xanthomonas citri 0053 cultured cells & 4 \\
\hline 7 & Exposed fruit (2 to 3 months) & 0 \\
\hline 8 & X. citri 0053 cultured cells & 4 \\
\hline 9 & 6-month-old fruit lesion & 2 \\
\hline 10 & Exposed fruit (2 to 3 months) & 1 \\
\hline 11 & Exposed fruit (2 to 3 months) & 0 \\
\hline 12 & 6-month-old fruit lesion & 1 \\
\hline 13 & X. citri 0053 cultured cells & 4 \\
\hline 14 & 3-month-old leaf lesion & 3 \\
\hline 15 & 6-month-old fruit lesion & 2 \\
\hline
\end{tabular}

${ }^{a}$ Experiment 1 occurred on 5 February 2002. Only red grapefruit leaves were sampled. Experiment 2 occurred on 12 April 2003. Red grapefruit leaves, fruit, and cultured cells were sampled as indicated. status. For this reason, we designed primers for citrus canker detection based on the most highly conserved sequences of the pthA gene. Primers VM3 and 4 exhibited high specificity and reacted with representative strains of all known canker groups.

Cubero and Graham (3) recently designed a pair of PCR primers named $J$-pth 1 and 2 , also based on the sequence of pthA. These primers proved useful in conventional PCR for detecting the target sequence in purified total DNA from $58 \mathrm{X}$. citri strains, including all known citrus canker groups and including strains of different geographical origins. Only one strain (of X. citri pv. aurantifolii B) did not amplify in their conventional PCR experiments, but sensitivity of these primers was not determined. Because (i) X. citri comprises clonal pathogenicity groups; (ii) representative strains of all known groups were detected with VM3 and 4 at a very high level of sensitivity; (iii) VM3 and 4 were designed to amplify a very short and invariant region of $p t h A$, and (iv) there is no reason to suspect that a xanthomonad could cause citrus canker disease without pthA or a functional homologue, we have no reason to expect that the VM3 and 4 primers would fail to detect any $X$. citri strain.

It should be noted that the avrBs3/pthA gene family is widely distributed in the genus Xanthomonas $(6,18)$; therefore, the VM3 and 4 primer pair should be able to identify strains of other Xanthomonas spp. and pathovars, such as X. oryzea (rice blight), $X$. phaseoli (common bean blight), and $X$. campestris pv. malvacearum (cotton blight). Indeed, these primers may be equally useful in detecting all strains of any species or pathovar in which a pthA homologue is required for pathogenicity (as appears to be the case for rice blight, cotton blight, and common bean blight) (7). Most xanthomonads are highly restricted in host range; therefore, there is little likelihood of a chance cross contamination causing a false positive result; for instance, by a rice blight strain being detected on a citrus sample, or vice versa. However, the sensitivity of the real-time PCR assay reported here means that this possibility would need to be experimentally assessed.

Effective control and eradication of citrus canker also requires reliable assay sensitivity. The assay developed here, including the sampling methods coupled with real-time PCR, enabled reliable detection of what appeared to be $<10 \mathrm{CFU}$ of $X$. citri from diseased leaf lesions. By contrast, $10 \mathrm{CFU}$ appeared to be the lower limit of detection of $X$. citri diluted from culture-grown cells. The apparent difference in sensitivity likely is due to the presence of

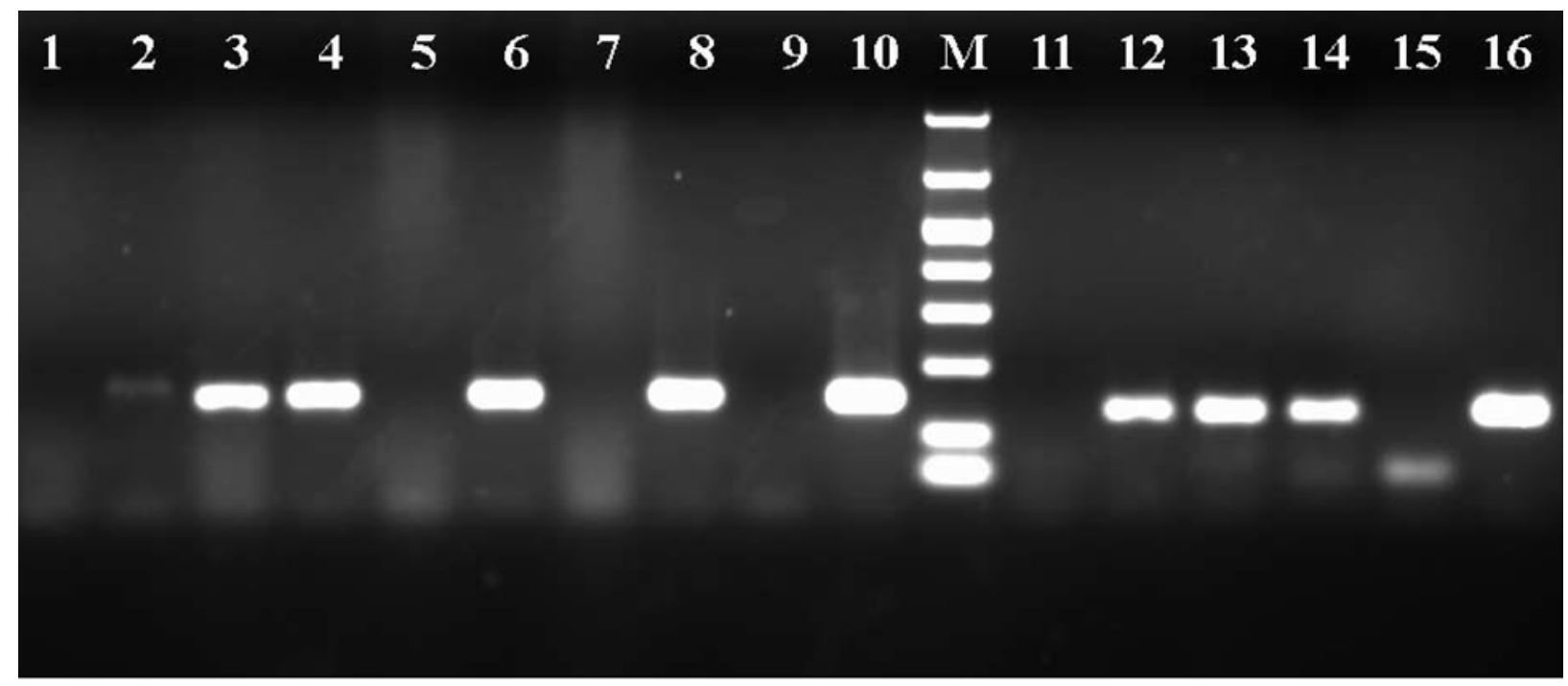

Fig. 2. Real-time polymerase chain reaction (PCR) products of the herbarium samples using direct tissue extracts or IT-purified DNA from the extracts, electrophoresed in $2 \%$ agarose gels and stained with ethidium bromide. Lanes 1 to 8: VM3 and 4 primer pair PCR products. 1, A1 extract; 2, A1 DNA; 3, A2 extract; 4, A2 DNA; 5, F3 extract; 6, F3 DNA; 7, F4 extract; 8, F4 DNA; 9, water control; 10, 10 ng of Xanthomonas citri 3213 DNA. Lanes 11 to 14: Kingsley's primer pair PCR products. 11, A1 DNA; 12, A2 DNA; 13, F3 DNA; 14, F4 DNA; 15, water control; 16 , 10 ng of $X$. citri pv. citri A DNA. Lane M, marker DNA (BioVentures Inc., Murfresboro, TN) of size: 1,000, 700, 525, 500, 400, 300, 200, 100, and $50 \mathrm{bp}$. 
additional $X$. citri DNA present in lesions from dead or nonviable cells; $X$. citri DNA was detected in 90-year-old herbarium citrus canker samples that had no detected living cells.

The ability to detect a lower limit of $10 \mathrm{CFU}$ of diluted culturegrown cells is consistent with the lower limit of detection of $0.1 \mathrm{pg}$ of purified $X$. citri total DNA. The $X$. citri main chromosome is $5.2 \times 10^{6} \mathrm{bp}$ in length, meaning on a per cell basis that it carries $5.2 \times 10^{6} \mathrm{bp} / \mathrm{cell}, 1 \mathrm{~mole} / 6.02 \times 10^{23} \mathrm{bp}, 660 \mathrm{~g} / \mathrm{mole}$, $10^{12} \mathrm{pg} / \mathrm{g}=0.006 \mathrm{pg}$ of single-copy (chromosomal) DNA per cell. $X$. citri also carries two different multicopy plasmids, one $33 \mathrm{~kb}$ and the other $64 \mathrm{~kb}$ in size. Assuming that each of the plasmids is estimated to be present at 10 copies per cell, this brings the total to $0.007 \mathrm{pg}$ of DNA per cell. Assuming half of the bacteria are present as clumps or with duplicated genomes due to incomplete cell division, then $10 \mathrm{CFU}=15$ bacteria, which should yield $0.105 \mathrm{pg}$ of DNA. This 10-CFU level of sensitivity is due in part to the fact that there are two homologues of pthA present on each of the two plasmids, or approximately 40 copies of the target sequence per cell or per $0.007 \mathrm{pg}$ of $X$. citri total DNA.

As previously mentioned, the $X$. citri bacteria detected using this PCR assay need not be viable, because the expected pthA sequence from herbarium leaf samples collected in the 1912 were amplified. To our knowledge, this is the first report of any successful molecular confirmation of the presence of $X$. citri from the 1912 canker outbreak in Florida. Repeated attempts by Gabriel (unpublished data) to resuscitate $X$. citri from these and other, similar herbarium samples or to detect $X$. citri DNA failed. Confirmation of historical diagnoses may be important if regulatory actions and scientific conclusions are based on the experienced behavior of a pathogen that is erroneously assumed to be $X$. citri. Even as recently as the 1980 s, both a fungal disease (Alternaria limicola) and a nursery leaf spot disease (X. campestris pv. citrumelo) were misdiagnosed as causing a "form" of citrus canker disease (8).

Real-time PCR offers a variety of amplicon detection methods; for a discussion of the relative merits of each method, refer Mackey et al. (19). We chose to use SYBR Green dye for fluorescence detection over fluorescent-labeled probes such as Taqman (Applied Biosystems) or hybridization probes because SYBR Green detection is less expensive, generates a stronger PCR signal, and is easy to optimize. Melting curve analyses allows differentiation of specific PCR products from nonspecific ones and from primerdimers. Moreover, fluorescence after each cycle can be acquired at temperatures higher than the Tm of primer-dimers and just under the Tm of the expected specific fragment, thus eliminating detection of nonspecific fluorescence. Once optimized, a SYBR Green real-time PCR assay can be easily modified for use with other detection formats, such as Taqman or hybridization probes.

Sample preparation was shown to be of paramount importance in sensitivity and reproducibility of this assay. We aimed at userfriendly, rapid sample preparation with minimal handling, preferably without a DNA extraction step. Of seven different sample preparation combinations, the best results were obtained when single lesions were crushed in $\mathrm{CaCO}_{3}$-Silwet L-77-Chelex and with the IT kit. Presence of $\mathrm{CaCO}_{3}$ was important for Xanthomonas cell survival because $\mathrm{CaCO}_{3}$-containing treatments proved to have the highest overall viable cell counts when plated on PYGM. Silwet L-77 is a surfactant and is useful in bacterial inoculations and in increasing apparent CFU in making cell counts (35).

Lesions cut with the smallest (no. 1) standard cork borer and crushed in $\mathrm{CaCO}_{3}$-Silwet L-77-Chelex appeared to release the most bacteria with the least amount of plant material and worked the best for all types and ages of lesion. Citrus sap is strongly inhibitory to PCR reactions (15); therefore, we found that the small cork borer was ideal in cutting just outside the boundary of a typical canker lesion, thus maximizing bacterial yield while minimizing contaminating plant tissue in the sample.
Samples crushed in $\mathrm{CaCO}_{3}-$ Silwet L-77 without Chelex had relatively higher $\mathrm{Cp}$ values and lower total fluorescence, even after extensive dilutions. The inhibition appeared to be due to the inhibitory effect of the crushed citrus. Chelex was used to prevent enzymatic degradation of DNA by chelating heavy metal ions that are needed by many DNases in low-salt conditions $(29,36)$. We found the combination of crushing the samples and including Chelex with the $\mathrm{CaCO}_{3}$ and Silwet to be most useful for extraction of old lesions or from poor citrus leaf samples.

The IT kit was subjected to only limited testing, but showed excellent accuracy, consistency, and reproducibility in detecting citrus canker from obviously infected field lesions on both leaves and fruit. DNA purification lowers level of inhibitors and minimizes background fluorescence. The sampling procedure using the IT kit is very easy and can be performed directly in the field by personnel with little technical background or training. The samples can be sent to a lab or the entire PCR process could be performed in a mobile field lab. The only equipment needed in addition to a field-hardened RAPID cycler are a low-speed centrifuge that comes with the instrument and a small vortex machine. Further comparative evaluation of this method is needed, particularly on older or damaged lesions.

The $\mathrm{CaCO}_{3}$-Silwet L-77-shaking method appeared to work very well with real field samples despite the fact that field samples very often were from old, dry leaves with some additional fungal or leaf miner contamination or damage. Each sample was set up in duplicate, which provided better quality control, especially for low-titer samples. The assay proved to be highly reproducibleeach sampling procedure resulted in consistent scores when comparable samples (lesions of the same age and quality) were used. The assay was quantitative and very sensitive, allowing detection of $X$. citri DNA from dead cells in canker lesions. Using real-time PCR with universal primers, we were able to accomplish fast and reliable detection of all of citrus canker strains with a minimum of labor in a total time of less than $4 \mathrm{~h}$. The assay described here could be very useful for fast and on-site citrus canker diagnosis for large-scale surveys in quarantine zones or ports of entry to prevent new introductions.

\section{ACKNOWLEDGMENTS}

This work was performed as part of a USDA-APHIS grant 99-81000578-CA to D. W. Gabriel, and is Florida Agriculture Experiment Station Journal Series R-09535. We thank T. Riley, USDA-APHIS, Fort Pierce, FL for collecting swab samples used; T. Schubert and X. Sun of the Division of Plant Industry, Florida Department of Agriculture, Gainesville, for providing citrus canker field samples used in some experiments; and M. Kingsley, Battelle Pacific Northwest National Laboratory, Richland, WA, for prepublication use of his primers and reaction conditions.

\section{LITERATURE CITED}

1. Brown, K. 2001. Florida fights to stop citrus canker. Science 292:22752276.

2. Brunings, A. M., and Gabriel, D. W. 2003. Xanthomonas citri: Breaking the surface. Mol. Plant Pathol. 4:141-157.

3. Cubero, J., and Graham, J. H. 2002. Genetic relationship among worldwide strains of Xanthomonas causing canker in citrus species and design of new primers for their identification by PCR. Appl. Environ. Microbiol. 68:1257-1264.

4. Cubero, J., Graham, J. H., and Gottwald, T. R. 2001. Quantitative PCR method for diagnosis of citrus bacterial canker. Appl. Environ. Microbiol. 67:2849-2852.

5. Duan, Y. P., Castaneda, A., Zhao, G., Ergos, G., and Gabriel, D. W. 1999. Expression of a single, host-specific, bacterial pathogenicity gene in plant cells elicits division, enlargement, and cell death. Mol. PlantMicrobe Interact. 12:556-560.

6. Gabriel, D. W. 1997. Targeting of protein signals from Xanthomonas to the plant nucleus. Trends Plant Sci. 2:204-206.

7. Gabriel, D. W. 1999. The Xanthomonas avr/pth gene family. Pages 3955 in: Plant-Microbe Interactions, vol. 4. G. Stacey and N. T. Keen, eds. The American Phytopathological Society, St. Paul, MN. 
8. Gabriel, D. W. 2001. Citrus canker. Pages 215-217 in: Encyclopedia of Plant Pathology. O. C. Maloy and T. D. Murray, eds. John Wiley \& Sons, New York.

9. Gabriel, D. W., Hunter, J., Kingsley, M., Miller, J., and Lazo, G. 1988. Clonal population structure of Xanthomonas campestris and genetic diversity among citrus canker strains. Mol. Plant-Microbe Interact. 1:5965.

10. Gabriel, D. W., Kingsley, M. T., Hunter, J. E., and Gottwald, T. R. 1989. Reinstatement of Xanthomonas citri (ex Hasse) and X. phaseoli (ex Smith) and reclassification of all $X$. campestris pv. citri strains. Int. J. Syst. Bacteriol. 39:14-22.

11. Gottwald, T. R., Graham, J. H., and Egel, D. S. 1992. Analysis of foci of Asiatic citrus canker in Florida citrus orchard. Plant Dis. 76:389-396.

12. Gottwald, T. R., Graham, J. H., and Schubert, T. S. 1997. An epidemiological analysis of the spread of citrus canker in urban Miami, Florida, and synergistic interaction with the Asian citrus leaf miner. Fruits 52:371-378.

13. Gottwald, T. R., Graham, J. H., and Schubert, T. S. 2002. Citrus canker: The pathogen and its impact. Online. Plant Health Progress doi:10.1094/PHP-2002-0812-01-RV.

14. Hartung, J. S., Daniel, J. F., and Pruvost, O. P. 1993. Detection of Xanthomonas campestris pv. citri by the polymerase chain reaction. Appl. Environ. Microbiol. 59:1143-1148.

15. Hartung, J. S., Pruvost, O. P., Villemot, I., and Alvarez, A. 1996. Rapid and sensitive colorimetric detection of Xanthomonas axonopodis pv. citri by immunocapture and nested-polymerase chain reaction. Phytopathology 86:95-101.

16. Heppner, J. P. 1993. Citrus leafminer, Phyllocnistis citrella, in Florida. Trop. Lepidoptera 4:49-64.

17. Kingsley, M. T., and Fritz, L. K. 2000. Identification of the citrus canker pathogen Xanthomonas axonopodis pv. citri A by fluorescent PCR assays. (Abstr.) Phytopathology 90(suppl.):S42.

18. Leach, J. E., and White, F. F. 1996. Bacterial avirulence genes. Annu. Rev. Phytopathol. 34:153-179.

19. Mackay, I. M., Arden, K. E., and Nitsche, A. 2002. Real-time PCR in virology. Nucleic Acids Res. 30:1292-1305.

20. Mills, D. 2002. Use of real-time PCR and high throughput detection of Clavibacter michiganensis subsp. sepedonicus. (Abstr.) Phytopathology 92(suppl.):S110.

21. Mumford, R. A., Walsh, K., Barker, I., and Boonham, N. 2000. Detection of potato mop top virus and tobacco rattle virus using a multiplex realtime fluorescent reverse-transcription polymerase chain reaction assay. Phytopathology 90:448-453.

22. Qi, M., and Yang, Y. 2002. Quantification of Magnaporthe grisea during infection of rice plants using real-time polymerase chain reaction and northern blot/phosphoimiging analyses. Phytopathology 92:870776.

23. Roberts, C. A., Dietzgen, R. G., Heelan, L. A., and Maclean, D. J. 2000. Real-time RT-PCR fluorescent detection of tomato spotted wilt virus. J. Virol. Methods 88:1-8.

24. Schaad, N. W., Berthier-Schaad, Y., Sechler, A., and Knorr, D. 1999. Detection of Clavibacter michiganesis subsp. sepedonicus in potato tuber by BIO-PCR and an automated real-time fluorescent detection system. Plant Dis. 83:1095-1100.
25. Schaad, N. W., Opgenorth, D., and Gaush, P. 2002. Real-time polymerase chain reaction for one-hour on-site diagnosis of Pierce's disease of grape in early season asymptomatic vines. Phytopathology 92:721-728.

26. Schubert, T. S., Gottwald, T. R., Rizvi, S. A., Graham, J. H., Sun, X., and Dixon, W. N. 2001. Meeting the challenge of eradicating citrus canker in Florida-again. Plant Dis. 85:340-356.

27. Schubert, T. S., Miller, J. W., and Gabriel, D. W. 1996. Another outbreak of bacterial canker on citrus in Florida. Plant Dis. 80:1208.

28. Sherman, D. J., Schneider, W. L., Stone, A. L., Damsteegt, V. D., and Frederick, R. D. 2002. Specific detection and quantification of plum pox potyvirus by real-time fluorescent RT-PCR. (Abstr.) Phytopathology 92(suppl.):S75.

29. Singer-Sam, J., Tanguay, R. L., and Riggs, A. D. 1989. Use of Chelex to improve the PCR signal from small number of cells. Amplifications: A Forum for PCR users. Issue 3:11.

30. Stall, R. E., and Civerolo, E. L. 1991. Research relating to the recent outbreak of citrus canker in Florida. Annu. Rev. Phytopathol. 29:339420.

31. Stevens, H. E. 1915. Studies of citrus canker. Fla. Agric. Exp. Stn. Bull. 124:31-53.

32. Sun, X., Stall, R. E., Cubero, J., Gottwald, T. R., Graham, J. H., Dixon, W. N., Schubert, T. S., Peacock, M. E., Dickstein, E. R., and Chaloux, P. H. 2000. Detection of a unique isolate of citrus canker bacterium from Key lime in Wellington and Lake Worth, Florida. (Abstr.) In: Proc. Int. Citrus Canker Res. Workshop, Ft. Pierce, FL. Online. Division of Plant industry. Florida Department of Agriculture and Consumer Services.

33. Swarup, S., De Feyter, R., Brlansky, R. H., and Gabriel, D. W. 1991. A pathogenicity locus from Xanthomonas citri enables strains from several pathovars of $X$. campestris to elicit cankerlike lesions on citrus. Phytopathology 81:802-809.

34. Swarup, S., Yang, Y., Kingsley, M. T., and Gabriel, D. W. 1992. A Xanthomonas citri pathogenicity gene, pthA, pleiotropically encodes gratuitous avirulence on nonhosts. Mol. Plant-Microbe Interact. 5:204213.

35. Tornero, P., and Dangl, J. L. 2001. A high-throughput method for quantifying growth of phytopathogenic bacteria in Arabidopsis thaliana. Plant J. 28:475-481.

36. Walsh, P. S., Metzger, D. A., and Higushi, R. 1991. Chelex 100 as a medium for simple extraction of DNA for PCR-based typing from forensic material. BioTechniques 10:506-513.

37. Weller, S. A., Elphinstone, J. G., Smith, N. C., Boonham, N., and Stead, D. E. 2000. Detection of Ralstonia solanocearum strains with a quantitative, multiplex, real-time, fluorogenic PCR (TaqMan) assay. Appl. Environ. Microbiol. 66:2853-2858.

38. Winton, L. M., Stone, J. K., Watrud, L. S., and Hansen, E. M. 2002. Simultaneous one-tune quantification of host and pathogen DNA with real-time polymerase chain reaction. Phytopathology 92:112-116.

39. Vandemark, G. J., Baker, B. M., and Gritsenko, M. A. 2002. Quantifying Aphanomyces euteiches in alfalfa with fluorescent polymerase chain reaction assay. Phytopathology 92:265-272.

40. Verniere, C., Hartung, J. S., Pruvost, O. P., Civerolo, E. L., Alvarez, A. M., Maestri, P., and Luisetti, J. 1998. Characterization of phenotypically distinct strains of Xanthomonas axonopodis pv. citri from Southwest Asia. Eur. J. Plant Pathol. 104:477-487. 